\title{
高速進展き裂コウスティックのホログラフィ記録*
}

\author{
鈴 木 新 一*1, 細 田 康 司*2
}

\section{Holographic Recording of Caustic Light Beams of Fast Propagating Cracks}

\author{
Shinichi SUZUKI and Yasuzi HOSODA
}

\begin{abstract}
A pulsed holographic technique is described which records and reconstructs caustic light beams of fast propagating cracks in polymethylmethacrylate (PMMA). A caustic light beam of a fast propagating crack is recorded as a hologram at an instant during its propagation with a pulsed holographic recording system. Illuminated with reconstruction light, the hologram reconstructs the caustic light beam, and diameters of caustics at various distances from the specimen are measured from the reconstructed caustic light beam. Values of dynamic stress intensity factor $K_{\mathrm{I}}$ and initial curve radii are calculated from the caustic diameters. The initial curve radius at which calculated $K_{\mathrm{r}}$ values deviate from the real $K_{\mathrm{I}}$ value gives the scale of the three-dimensional stress field which appears around the fast propagating crack tip. In the case of cracks propagating through specimens $3 \mathrm{~mm}$ in thickness, the 3-D stress field spreads as far as the distance of half of the specimen's thickness from the tip.
\end{abstract}

Key Words : Fracture, Measurement, Optical Engineering, Holography, Caustic, Dynamic Fracture, Three-Dimensional Stress Field

\section{1. ま え がき}

板厚 $t$ の無限平板中の半無限き裂において, き裂先 端からある程度離れた場所には， $1 / \sqrt{r}$ （ $r$ はき裂先端 からの距離) の特異性を持つ平面応力場が存在す $る^{(1) \sim 4)}$. しかし，き裂先端近傍では，三次元応力場が 支配的となってくる(5) -(13) (図 1 参照).この三次元応力 場がき裂先端からどの程度の距離まで広がっているか は, き裂先端部の応力場を理解するうえで重要な問題 である。

Yang and Freund ${ }^{(12)}$ は, 静止き裂において, 三次元 応力場の成立する範囲は, き裂先端から板厚の半分程 度までであることを理論的に示した。 また Rosakis and Ravi-Chandar ${ }^{(13)}$ は，静止き裂にコウスティック 法(14) (17)を適用することにより，上記の理論結果を支 持する実験結果を得た。それより以前に，島田・佐々 木 $^{(10)}$, Shimizu ら ${ }^{(11)}$ は, コウスティック法を用いた 応力拡大係数の測定に拉ける測定誤差の要因の一つと

\footnotetext{
* 昭和 63 年 11 月 16 日 第 954 回講演会において講演、原稿 受付 昭和 63 年 12 月 28 日.

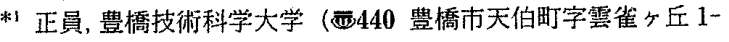
1).

*2 学生, 䅧橋技術科学大学大学院.
}

して三次元応力場の影響を調べており, 彼らの実験結 果は Rosakis and Ravi-Chandar の赛験結果と良く 一致している.これらの研究から, 静止き裂において は, 三次元応力場の成立する範囲は, き裂先端から板 厚の半分程度であると言える.しかしながら, 数百 $\mathrm{m} /$ $\mathrm{s}$ の高速で進展しているき裂先端部の, 三次元応力場 が,き裂先端からどの程度の距離まで広がっているか は，いまだ末知の問題である。本研究は，この問題に対 して実験的解答を与える能力を有するパルスホログラ フィ法に関するものである。

パルスホログラフィは，これまで海中微生物の観

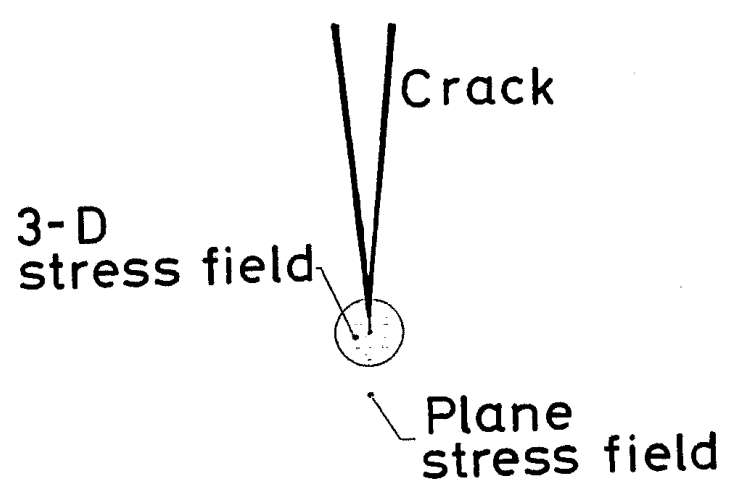

図 1 き裂先端付近の応力場 
察 ${ }^{(18)}$, 振動解析 ${ }^{(19)}$, 流れの可視化 ${ }^{(19)}$, 微粒子挙動の解 明 ${ }^{(19)}$, 高速進展き裂先端部の顕微鏡撮影(20)等に用い られてきた.ホログラフィは, 基本的には, 光の波面再 生法であり ${ }^{(21) \sim(23)}$, 物体光を 1 枚のホログラムとして 記録し，再生する手法である。

清水・島田 ${ }^{(9)}$, 島田・佐々末 ${ }^{(10)}$, Shimizu ら ${ }^{(11)}$, Rosakis and Ravi-Chandar ${ }^{(13)}$ は, 静止き裂のコウスティ ック径 ${ }^{(14) \sim(16)}$ をイニシャルカーブ半径を変えて測定す ることにより，三次元応力場の大きさを明らかにし た. 同様の手法を高速進展き裂に適用するためには， 進行するき裂の, ある瞬間におけるコウスティック径 を, 試験片からの距離を変えて同時に測定する必要が ある. 光の波面再生法であるホログラフィは, これを 可能にする最も有力な手法である. 以下にパルスレー ザを光源に用いた，高速進展き裂コウスティックの， ホログラフィ記録に関して述べる.

\section{2. 三次元応力場の成立する範囲の 測定原理 ${ }^{(13)}$}

本研究では試験片に, 光学的に等方な透明 PMMA 平板(住友化学工業製, スミペックス $\mathrm{E}$ )を用いる. PMMA 試験片中の, 開口形き裂の応力拡大係数を, 透過形コウスティック法を用いて測定する場合, 次の ようになる(図 2 参照)，試験片面に対して垂直に平行 光線を入射させる。き裂先端周辺での試験片板厚の変 化と屆折率の変化によって，光は外側に曲げられ，試 験片面から $Z_{0}$ の位置にあるスクリーンに到達する. その結果スクリーンに, 光の到達しない影の領域(シ ヤドースポット)が，そしてその外側に光の集中する

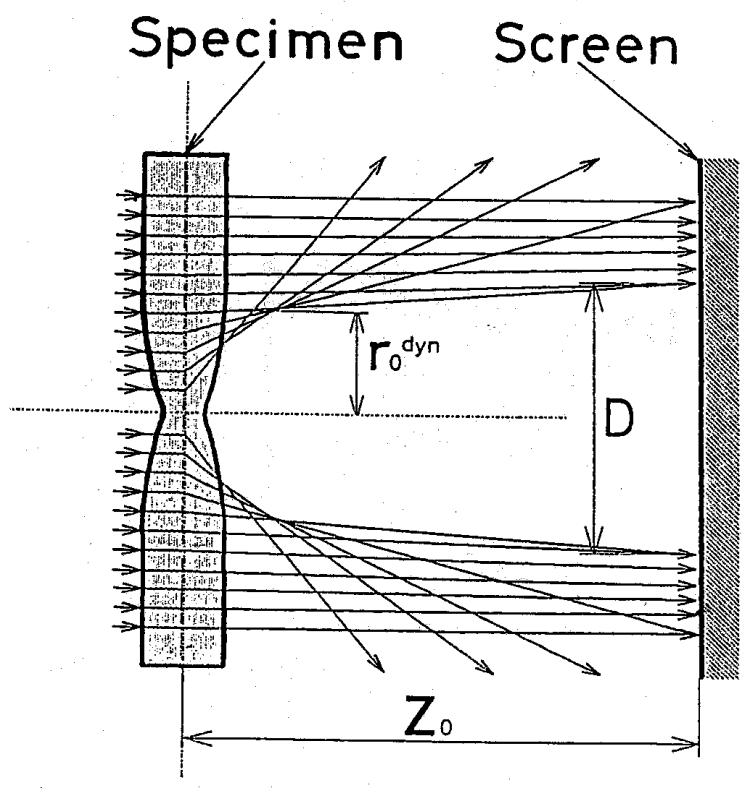

図 2 コウスティック法を用いた応力拡大係数の測定
コウスティックが形成される、コウスティック径 $D$ (き裂と直角方向の最大径) は, $Z_{0}$ の $5 / 2$ 乗に比例す $る^{(15)(16)}$.

$$
D=\alpha Z_{0}^{5 / 2}
$$

コウスティック上の一点から, 光の来た道筋を逆に たどると試験片面上の一点に到達する。このようなこ とを，コウスティック上のあらゆる点について行うと， 試験片面上に 1 本の曲線を描くことができる。これが イニシャルカーブである．静止き裂の場合，イニシャ ルカーブは円になる。また高速進展き裂においても， 良い近似で円とみなすことができる ${ }^{(15)}$. PMMA 試験 片の場合コウスティック径 $D$ とイニシャルカーブ半 径 $r_{0}^{d y n}$ との関係は

$$
D=3.17 r_{0}^{d y n}
$$

と書ける ${ }^{(15)}$. 試験片からスクリーンまでの距離を小さ くとれば,コウスティック径 $D$ は小さくなり,イニシ

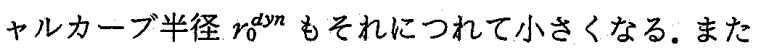
コウスティック法では, コウスティック径 $D$ を測定 することにより, 動的応力拡大係数 $K_{\mathrm{I}}^{\mathrm{EXP}}$ を求めるこ とができる(14) (16).

$$
K_{\mathrm{I}}^{\mathrm{EXP}}=\beta \frac{1}{F(v)} D^{5 / 2}
$$

ここで $\beta$ は, 試験片材料や試験片からスクリーンまで の距離で決まる比例定数, $F(v)$ は，き裂進展速度の影 響を表す関数である。

コウスティック法では，き裂先端近傍で，1/ $\sqrt{r}$ の 特異性を持つ平面応力場が成立していることを仮定し ており，イニシャルカーブがその平面応力場の範囲内 にあれば, 式 (3)は常に真の動的応力拡大係数 $K_{1}^{2 D}$ を与える $\left(K_{1}^{\mathrm{EXP}}=K_{1}^{2 D}\right)$. しかしイニシャルカーブが三 次元応力場の中にある場合には，式 (3) から算出され る動的応力拡大係数 $K_{\mathrm{I}}^{\mathrm{EXP}}$ は, 真の動的応力拡大係数 $K_{\mathrm{I}}^{2 D}$ からずれることになる(9) (11)(13).

このことを逆に利用して、コウスティック法によっ て計算された動的応力拡大係数 $K_{\mathrm{I}}^{\mathrm{EXP}}$ と真の動的応力 拡大係数 $K_{\mathrm{I}}^{2 D}$ とのずれから，三次元応力場がき裂先 端からどの程度の距離まで支配的であるかを知ること ができる，すなわち，試験片からスクリーンまでの距 離 $Z_{0}$ を減少させながらコウスティック径 $D$ を測定 し，式（3）でそれぞれの $K_{\mathrm{l}}^{\mathrm{EXP}}$ を計算する。，その $K_{\mathrm{l}}^{\mathrm{EXP}}$ が, 真の動的応力拡大係数 $K_{\mathrm{l}}^{2 D}$ からずれ始めるとこ ろのイニシャルカーブ半径が, 三次元応力場の広がり を与える. Rosakis and Ravi-Chandar ${ }^{(13)}$ は, 上記の測 定原理を静止き裂に対して適用し，き裂先端部に発生 する三次元応力場の大きさが試験片板厚の $1 / 2$ 程度で あることを示した．本研究ではコウスティックのパル 
スホログラフィ記録を用いることにより，上記の測定 原理を高速進展き裂に対して適用する。

\section{3. コウスティックの} ホログラフィ記録および再生

高速進展き裂コウスティックのホログラフィ記録に 用いた光学系を図 3 に示す. 試験片 SP には，モード I 形の引張荷重がかけられている，破壊が誘起され， き裂が観測領域に入ったときに，パルスレーザ PLが 一度発振する.観測領域内には導電性叙料が塗布され ており，それらが切断されるときの信号を用いて，き 裂速度が測定される ${ }^{(20)}$. パルスレーザから出た光は， 凹レンズ L1 で広げられた後, ビームスプリッタ BS で二方向に分けられる．ビームスプリッタで反射した 光は, カメラレンズ L 4, L 5 を通って平行光線にされ る.この光は試験片を透過した後, ホログラフィ乾板 HP に垂直に入射する．これが物体光である．すなわ ち, 高速進展き裂のコウスティック光が物体光とな る.試験片からホログラフィ乾板までの距離 $Z_{h}$ は 150 $\mathrm{mm}$ である. 一方ビームスプリッ夕を透過した光は， カメラレンズ L 2, L 3 で平行光線にされ，ホログラフ イ乾板に物体光と $\theta$ の角をなして入射する.これが参 照光である．このようにして，物体光を千渉縞の形で ホログラフィ乾板に記録する。

現像処理されたホログラフィ乾板(ホログラム)に, 記録時と同じ波長の光 (再生光)を照射して, 物体光を 再生する，以下に物体光の再生，およびコウスティッ

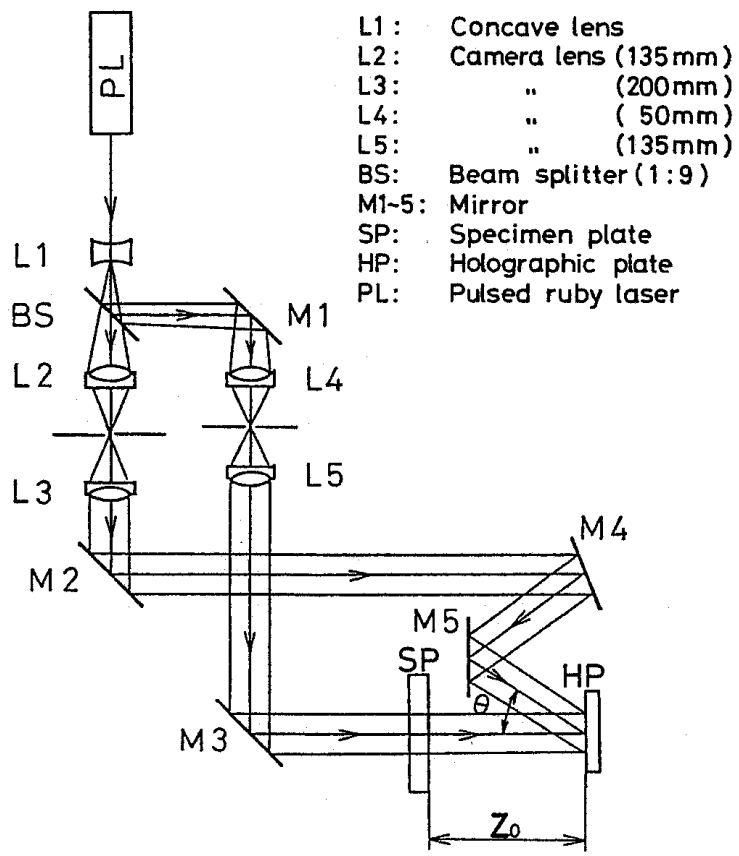

図 3 コウスティック光のホログラフィ記録用光学系
ク像の撮影方法について述べる。

図 4(a)は，試験片から見て乾板よりも遠い位置 $\left(Z_{0}>Z_{h}\right)$ での物体光の再生と, コウスティック像の撮 影方法について示したものである．再生には，記録時 と同じ光学系を用いる.ホログラムに参照光と同じ角 度 $\theta$ で同じ方向から再生光を入射させると，ホログラ ムから，記録時と全く同じ物体光が再生される．この とき，乾板のあった位置よりも遠方 $\left(Z_{0}>Z_{h}\right)$ にフィル 厶を置き，その位置でのコウスティック像を撮影す る。

試験片と乾板の間 $\left(Z_{0}<Z_{h}\right)$ の物体光の再生と, コウ スティック像の撮影方法を図 4(b) に示す. 参照光と 同じ角度 $\theta$ で参照光とは逆の方向から再生光を入射 させる.すなわち, 参照光の共役光を再生光に使う.す るとホログラムから試験片があった方向へ，物体光と 同じ光が，逆向きに再生される.つまり，ホログラフィ 記録された物体光の共役光が再生される.したがって， 試験片とホログラムの間の位置にフィルムを置けば,

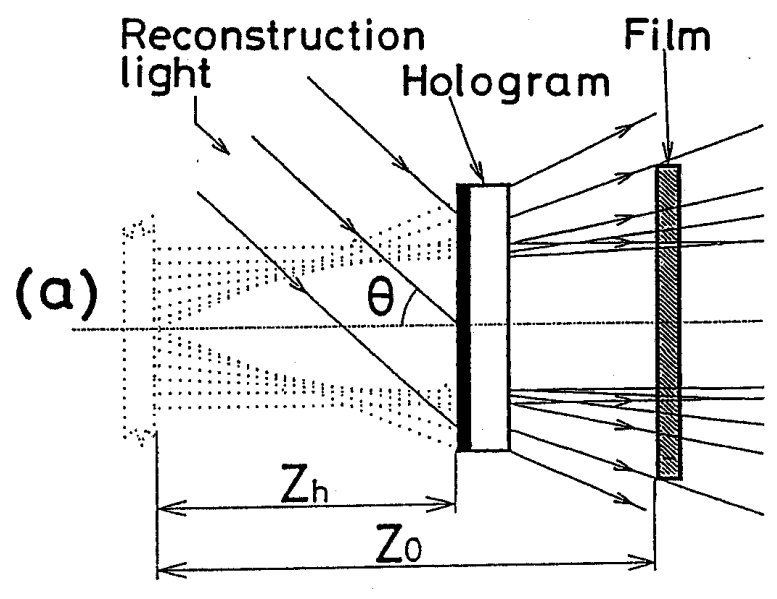

（a）乾板より遠方のコウスティック光の再生方法

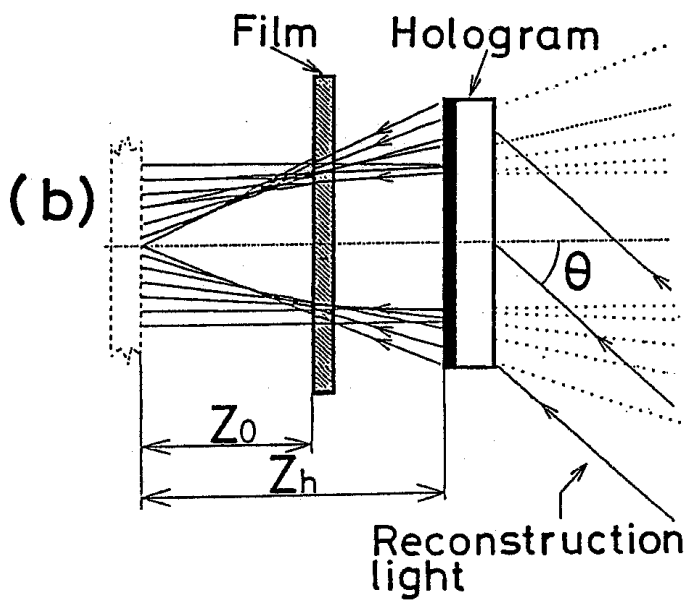

（b）試験片と乾板の間のコウスティック光の再生 図 4 コウスティック光の再生方法 
試験片とホログラムの間のコウスティック像を撮影す ることができる、実際には，記録時と同じ光学系を用 い,ホログラムを裏返しにして再生を行った。

以上のような手法で, フィルムの置く位置を次々と 変えることにより, 高速進展き裂の瞬間的なコウステ

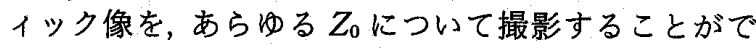
きる。

\section{4. 実験結果および考察}

図 5 は, 板厚 $3 \mathrm{~mm}$ の試験片を $601 \mathrm{~m} / \mathrm{s}$ の速度で進 行するき裂のコウスティックの，ホログラフィ再生像 である.（a）は試験片面からの距離 $Z_{0}$ が $1200 \mathrm{~mm} の$ 位置での写真であり, $Z_{0}>Z_{n}$ の場合のコウスティッ ク像の一例である. $Z_{0}<Z_{h}$ の場合のコウスティック像 の写真の一例を (b)に示す. 試験片面からの距離 $Z_{0}$ は $25 \mathrm{~mm}$ である. 試験片に近いほうの像も遠い像も 鮮明なコウスティックが得られている。このような写 真からコウスティック径 $D$ を測り，イニシャルカー ブ半径 $r_{0}^{d y n}$ および動的応力拡大係数 $K_{1}^{\mathrm{ExP}}$ を求める.

図 6 は, 板厚 $3 \mathrm{~mm}$ の試験片中を進行するき裂の, コウスティック径から求めたイニシャルカーブ半径 と, 動的応力拡大係数の関係を示したものである， $Z_{0}$

$$
\text { N 0. } 23 \mathrm{~V}=601 \mathrm{~m} / \mathrm{s}
$$

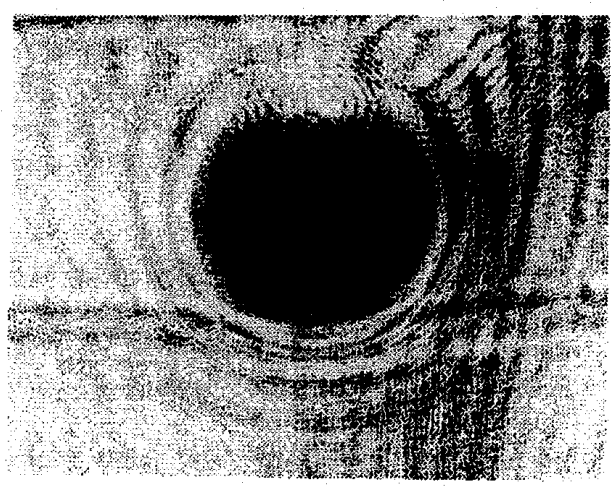

(a) $Z_{0}=1200 \mathrm{~mm}$

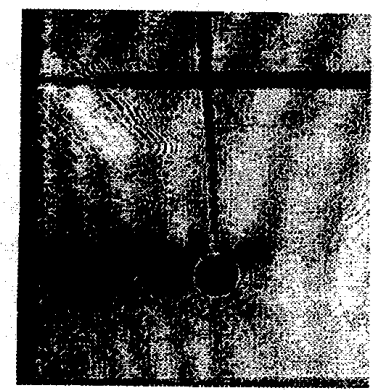

(b) $Z_{0}=25 \mathrm{~mm}$

図 5 高速進展き裂コウスティックのホログラフィ再生像
$=25 \mathrm{~mm}$ から $3200 \mathrm{~mm}$ までの 16 点でコウスティッ ク径を測定した。横軸は，イニシャルカーブ半径 $r_{0}^{d y n}$ を板厚 $t$ で割って無次元化したもの, 縦軸は, コウス ティック法で得られた動的応力拡大係数 $K_{\mathrm{I}}^{\mathrm{EXP}}$ を真の. 動的応力拡大係数 $K_{\mathrm{I}}^{2 D}$ で無次元化したものである.

この図からイニシャルカーブ半径 $r_{0}^{d y n}$ が試験片板 厚の $1 / 2$ より大きい所では、コウスティック法で得ら れた $K_{\mathrm{l}}^{\mathrm{EXP}}$ は一定の值を示している。したがってこの 領域では，イニシャルカーブは平面応力場の中にある と考えられ, 得られた $K_{\mathrm{I}}^{\mathrm{EXP}}$ は, 真の動的応力拡大係 数 $K_{\mathrm{l}}^{2 D}$ を与える. 図 6 の縦軸の無次元化には, この值 を用いた。

一方 $r_{0}^{d y n}$ が板厚の $1 / 2$ よりも小さい所では,コウ スティック法で得られた $K_{\mathrm{I}}^{\mathrm{ExP}}$ は, 真の応力拡大係数 $K_{1}^{2 D}$ よりも小さな值を示している。このことは, き裂 先端からの距離が試験片板厚の $1 / 2$ 以下の所では, 応 力場は平面応力状態から逸脱し，三次元応力場が支配 的となっていることを示している.この結果は, 島田・ 佐々木 ${ }^{(10)}$, Shimizu $ら^{(11)}$, Rosakis and Ravi-Chandar ${ }^{(13)}$ が静止き裂で得た結果と一致する.すなわち, 本 研究で取扱われた高速進展き裂では, 三次元応力場の 広がりに対するき裂速度の影響は小さいと言える。こ の理由として，以下のことが考えられる。

(1) PMMA 中の横波速度は $998 \mathrm{~m} / \mathrm{s}$ であり，本

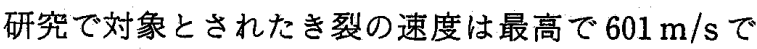
ある.すなわち，き裂速度は横波速度の約 $60 \%$ であ る.この速度では, き裂が進行しているために生じる 応力場の変化は静止き裂の応力場の $30 \%$ 程度(4)であ るため, 三次元応力場の広がりを極端に変化させるも のではない.

（2）き裂先端からある程度離れた所では平面応力 状態が実現している。 また, 材料内部でき裂先端のご

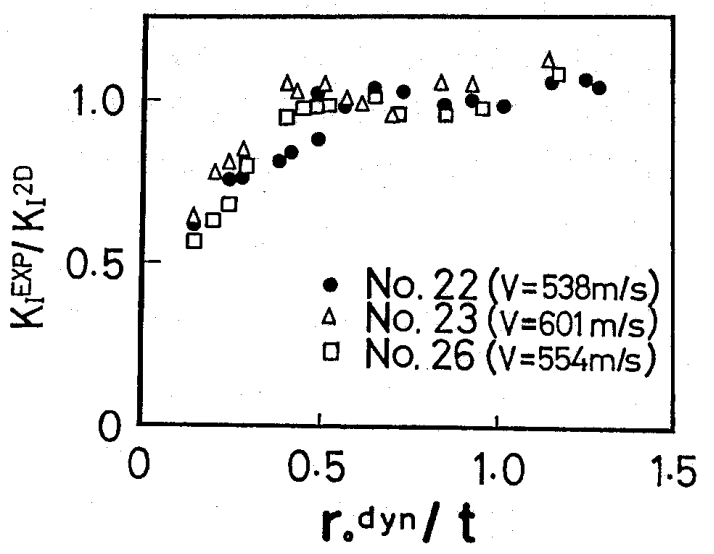

図 6 コウスティック法から得られる動的応力 拡大係数とイニシャルカーブ半径の関係 
く近傍では平面ひずみ状態が実現している，き裂先端 近傍の三次元応力場はこの平面応力場と平面ひずみ場 との境界領域に現れる. 平面ひずみ場に対するき裂速 度の効果と平面応力場に対するそれとは同じょうなも のであり(4)，したがって，三次元応力場の広がりはき 裂速度に対して鈍感である。

（3）コウスティック径を測定して求められる三次 元応力場の広がりは, き裂の進行方向から $72^{\circ}$ の角度 を成す方向での広がりを意味する，高速進展き裂前方 の応力場はき裂速度の影響を最も大きく受けるが, き 裂の進行方向から $72^{\circ}$ の方向では, それに比心゙て, き 裂速度の影響は小さい(15) (17).

上記のうち，どれか一つが支配的なのか(そうだと するなら，それはどれか)，それともいくつかが複合的 に起こっているのか, 現在のところ, 不明である.

本研究で用いた試験片板厚 $(3 \mathrm{~mm})$ よりも厚い板厚 の試験片を用いて，三次元応力場の広がりに対する板 厚の効果を測定するには, 本研究でコウスティック光 用に使用した平行光線よりも平行度の良い光を用いる 必要がある。例えば板厚 $5 \mathrm{~mm}$ の試験片を用いて, 図 6 と同じ様に， $r_{0}^{d y n} / t=1.3$ までの $K_{1}^{\mathrm{EXP}}$ を測定するに は, $Z_{0}=11 \mathrm{~m}$ の所までコウスティック径を測定する 必要がある。本研究でコウスティック光用に使用した 光は, $Z_{0}=3.2 \mathrm{~m}$ の所までは平行光線とみなされる.し かし $Z_{0}$ がそれより大きいところではレンズの収差と レンズ外縁での光の回折の影響が現れてくる.このた め板厚 $5 \mathrm{~mm}$ の試験片を用いた寒験では十分な精度 でのコウスティック径の測定がなされなかった。より 高い平行度を持つ光を用いた板厚効果に関する実験 は，次の機会に報告されるであろう。

\section{5. 結 論}

パルスレーザを用いた高速進展き裂コウスティック のホログラフィ記録は，き裂先端近傍の三次元応力場 の成立する範囲を測定するうえで有効な手法である. 本研究の実施にあたり, 本学学生, 福地信吾君, 加藤 宗寿君の多大な協力を得た。ここに感謝する。

\section{文献}

(1) Yoffe, E. H.. The Moving Griffith Crack, Phil. Mag., 42 (1951), 739.

(2) Craggs, J. W., on the Propagation of a Crack in an Elastic-Brittle Material, J. Mech. Phys. Solids, 8(1960), 66 .

(3) Achenbach. J. D. and Tolikas, P. K.. Elastodynamic
Effects on Crack Arrest, ASTM STP, 627(1977), 59.

（4）青木，動破壞力学と動的破壊じん性，材料，33-365(1984), 229.

(5) Dudderar, T. D. and O'Regan, R., Measurement of the Strain Field Near a Crack Tip in Polymethylmethacrylate by Holographic Interferometry, Exp. Mech., 11 (1971), 49.

(6) Folias, E. S., On the Three-Dimensional Theory of Cracked Plates, Trans. ASME, J. Appl. Mech. 42 (1975), 663.

(7) Benthem, J. P., State of Stress at the Vertex of a Quarter-Infinite Crack in a Half-Space, Int. J. Solids Struct., 13(1977), 479.

(8) Bažant, Z. P. and Estenssoro, L. F., Surface Singularity and Crack Propagation, Int. J. Solids Struct., 15 (1979), 405.

（9）清水・島田, Caustics (Shadow) 法による応力拡大係数の 測定について, 非破壊検查, 27-7(1978), 399.

（10）島田・佐々木，表面反射形 Caustics 法に上る応力拡大係 数の測定, 機論, 49-441, (1983), 579 .

(11) Shimizu, K., ほか 2 名, Some Propositions on Caustics and an Application to the Biaxial-Fracture Problem, Exp. Mech., 25-2(1985), 154.

(12) Yang, W. and Freund, L. B., Transverse Shear Effects for Through-Cracks in an Elastic Plate, Int. J. Solids Struct., 21-9(1985), 977.

(13) Rosakis, A. J. and Ravi-Chandar, K., on Crack-Tip Stress State: an Experimental Evaluation of ThreeDimensional Effects, Int. J. Solids Struct., 22-2(1986), 121.

(14) Manogg, P., Schattenoptische Messung der Spezifischen Bruchenergie Während des Bruchvor. gangs bei Plexiglas, Proc. Int. Con. Physics Non-Cristalline Solids, Delft, The Netherlands, (1964), 481.

(15) Beinert, J., ほか 2 名, Neuere Ergebnisse zur Anwendung des Schattenfleckverfahrens auf Stehende und schnell-laufende Brüche, Proc. 6th Int. Con. Exp. Stress Anal., VDI-Report, No.313(1978), 791.

(16) Rosakis, A. J., Analysis of the Optical Method of Caustics for Dynamic Crack Propagation, Eng. Fract. Mech., 13(1980), 331.

（17）西岡・橘高, 混合モード高速進展き裂のコースティック法 理論 (第 1 報, 面内混合モード理論), 機論, 54-501, (1988), 1061.

(18) Knox, C., Holographic Microscopy as a Technique for Recording Dynamic Microscopic Subjects, Science, 153 (1966), 989.

(19) Koechner, W. (Stitch, M. L. 編), Pulsed Holography, Laser Handbook 3 North-Holland, (1979), 577.

(20) Suzuki, S., ほか 2 名, Pulsed Holographic Microscopy as a Measurement Method of Dynamic Fracture Toughness for Fast Propagating Cracks, J. Mech. Phys. Solids, 36-6(1988), 631.

(21) Gabor, D., a new Microscopic Principle, Nature, 1614098 (1948), 777.

(22) Leith, E. N. and Upatnieks, J.. Wavefront Reconstruction with Diffused lllumination and Three-Dimensional Objects, J. Opt. Soc, Am., 54-11(1964), 1295.

(23) Smith, H. M., Principles of Holography (2nd edn), Wiley, New York, (1975). 